УДК 343.431

DOI https://doi.org/10.32837/pyuv.v0i1(30).538

\author{
Н. А. Гураленко \\ orcid.org/0000-0003-0884-215X \\ доктор юридичних наук, доиент, \\ доцент кафедри людських прав \\ Чернівецького національного університету імені Юрія Федьковича \\ T.С. Коханюк \\ orcid.org/0000-0002-5816-9680 \\ кандидат юридичних наук, \\ завідувач відділення організації освітньо-наукової підготовки \\ (докторантури та аспірантури (ад'юнктури)) \\ Львівського державного університету внутрішніх справ
}

\title{
ПРОТИДІЯ ТОРГІВЛІ ЛЮДЬМИ В УКРАЇНІ: ШШЛЯХИ ВДОСКОНАЛЕННЯ ПРАВОВОЇ ПОЛІТИКИ
}

Увага світової спільноти, що спрямована на констатування проблеми захисту основних прав людини як фундаментальної основи будь-якого суспільства в площині протидії торгівлі людьми, надзвичайно важлива.

Торгівля людьми - це форма насильства, що спричиняє ризик для життя та здоров'я людини, посягає на її невіддільні права і свободи - право на гідність, на свободу та особисту недоторканість, свободу пересування і вільний вибір місця проживання. Подібно до інших форм злочинної діяльності торгівля людьми динамічна, схильна до адаптації, має мінливий характер. Як надмірний достаток, так і критична бідність можуть їй сприяти. У першому випадку формуються «споживачі» товару, а в другому - «продукт» їхнього споживання - власне «живий» товар. Водночас звична констатація проблеми не в змозі щось змінити без чітко орієнтованих норм та механізмів такого захисту. Лише дія сформованих державою та міжнародною спільнотою систем інститутів здатна оберегти індивіда від свавілля з боку інших суб'єктів, а цивілізовані формальні проекції трансформувати з теоретичної у практичну площину.

Проблема торгівлі людини постійно знаходиться в центрі уваги різних напрямів наукової думки - юриспруденції, політології, історії, соціології, психології. Над її розробкою працюють чимало провідних інститутів, лабораторій, міжрегіональних центрів реабілітації внутрішньодержавного рівня. У боротьбі з торгівлею людьми важливу роль відіграють і міжнародні інституції (Організація Об’єднаних Націй, Міжнародна організація праці, Міжнародна організація з питань міграції та інші), які активно проголошують правозахисний підхід до розв'язання цієї проблеми.

У вітчизняній юридичній літературі питання формування та реалізації державної політики протидії торгівлі людьми крізь призму характе- ристики цього явища як однієї із форм злочинної діяльності, визначення його причинно-наслідкового складника, нормативного та інституційного забезпечення, вивчали О.В. Александренко, Н.О. Веселовська, О.О. Дивущак, К.Ю. Дядюра, Н.С. Карпов, В.П. Ковальчук, В.В. Турок та інші.

Метою статті $\epsilon$ аналіз вітчизняної правової політики протидії торгівлі людьми та надання рекомендацій щодо шляхів її вдосконалення.

Правова політика протидії торгівлі людьми на державному рівні повинна мати комплексний характер й передбачати запровадження дієвих заходів у трьох напрямах: по-перше, це попередження торгівлі людьми; по-друге, це боротьба зі злочинністю, що пов'язана з торгівлею людьми; по-третє, комплексна допомога та захист постраждалих від торгівлі людьми. Враховуючи зазначене, під час реформування правової політики у вищезгаданій площині слід враховувати наступне:

1. Одноосібна боротьба 3 торгівлею людьми з боку владних структур чи з боку громадських активістів не може бути ефективною, у цьому процесі важлива взаємодія як урядових, так й неурядових суб'єктів (превентивна робота громадських організацій у вигляді лекцій, інтерактивних занять, культурних заходів, їх активність у залученні органів влади, ЗМІ до даної проблеми).

У системі такоїспівпраціодним з варіантівефективної взаємодії задля збільшення кількості поінформованих осіб з проблематики торгівлі людьми та забезпечення доступу постраждалих осіб до дієвої допомоги можуть стати офіційний статус державних органів та волонтерські й фінансові можливості неурядових організацій. На противагу зазначеному, недіючими (хоча й досить поширеним на практиці в Україні) виявляються такі популярні форми взаємодії, як: соціальне замовлення на проекти програм громадських організацій (у цьому разі мають місце або корупційна схема, 
або відсутність належного фінансування) та формування так званих «кишенькових» неурядових організацій при органах влади (створюються насамперед з метою залучення коштів міжнародних донорських організацій для реалізації запланованих заходів владних структур, формування ілюзії взаємодій впливу громадянського суспільства).

2. В Україні кримінально-правовою основою протидії торгівлі людьми виступає Кримінальний кодекс України [6], який передбачає відповідальність за торгівлю людьми або іншу незаконну угоду щодо людини (ст. 149 КК), порушення встановленого законом порядку трансплантації органів або тканин людини (ст. $143 \mathrm{KK})$, насильницьке донорство (ст. $144 \mathrm{KK})$, експлуатацію дітей (ст. 150 КК), використання малолітньої дитини для заняття жебрацтвом (ст. 150-1 КК), незаконні дії щодо усиновлення (удочеріння) (ст. 169 КК), шахрайство (ст.190 КК), ввезення, виготовлення або розповсюдження творів, що пропагують культ насильства і жорстокості (ст. 300 КК), ввезення, виготовлення, збут і розповсюдження порнографічних предметів (ст.301 КК), створення або утримання місць розпусти і звідництво (ст. 302 КК), незаконне переправлення осіб через державний кордон України (ст. 332 КК).

Стратегія боротьби зі злочинністю у нашій державі переходить до системного впливу на неї, передбачає втілення комплексних загальносоціальних та кримінально-правових програм протидії цьому негативному явищу. При цьому слід зауважити, що всі зусилля держави спрямовані переважно на опрацювання заходів впливу на осіб, які вчиняють злочини. Водночас заходи віктимологічної профілактики часто мають фрагментарний характер, а особа потерпілого розглядається як джерело інформації про злочин або злочинця.

Однією із центральних проблем у протидії торгівлі людьми в Україні є відшкодування потерпілим цього злочину шкоди. Традиційно основним способом такого відшкодування виступає реституція, тобто пред'явлення цивільного позову до винного або відповідального за відшкодування збитків особі. Разом із тим реституція не завжди гарантує задоволення інтересів потерпілого, що зумовлено наступними обставинами: по-перше, відсутністю у більшості осіб, визнаних винними у вчиненні злочину, необхідного майна або доходів, що дозволяють відшкодувати заподіяну злочином шкоду; й, по-друге, не встановленням слідчими органами осіб, винних у скоєнні значної частини злочинів, що повністю позбавляє потерпілого надії на відшкодування заподіяної йому злочином шкоди.

Реальним механізмом надання допомоги та захисту жертв насильства, у тому числі й у випадках торгівлі людьми, є відшкодування за рахунок держави матеріальної шкоди постраждалим від цього злочину. Такий підхід можна обгрунтувати таким чином: обов'язком держави є підтримання правопорядку та забезпечення прав кожного члена суспільства, а тому у випадках бездіяльності запобігання злочину торгівлі людьми, вона повинна усунути всі негативні наслідки злочинного посягання, у тому числі шляхом відшкодування заподіяної шкоди. Незважаючи на те, що злочинець і залишається головним суб'єктом відшкодування шкоди, держава повинна взяти на себе тимчасові посередницькі функції з метою негайного правового, соціального захисту і матеріальної підтримки потерпілої особи.

Важливим кроком у цьому напрямі могла бути ратифікація Україною Європейської конвенції про відшкодування збитків жертвам насильницьких злочинів (1983 р.), підписаної нашою державою ще у 2005 р. Відповідно до ст. 2 зазначеної Конвенції передбачено: «коли відшкодування збитків не може бути забезпечено за рахунок винної особи чи з інших джерел, держава повинна взяти на себе відповідне зобов' язання для наступних категорій: по-перше, особам, яким у результаті навмисних насильницьких злочинів була нанесена серйозна втрата фізичного чи психічного здоров'я; й, по-друге, особам, що знаходились на утриманні загиблих внаслідок такого злочину» [5].

Якщо виходити з міжнародних стандартів, реалізація прав постраждалих від торгівлі людьми пов'язана з наданням такій особі інформації про роль та обсяг належних їй прав, строки та результати їх здійснення. У зв'язку із цим в Україні проблемним залишається питання забезпечення потерпілої особи якісною правовою допомогою. Реалізувати це завдання можна на законодавчому рівні шляхом включення постраждалих від торгівлі людьми до категорії осіб, які мають право на безоплатну правову допомогу. Раціональність такого підходу обгрунтовується таким чином: постраждалі зазвичай не в змозі представити всі необхідні документи для підтвердження статусу суб'єкта права на безоплатну вторинну правову допомогу, передбачені Законом України «Про безоплатну правову допомогу» [2] та Методичними рекомендаціями щодо організації надання безоплатної вторинної правової допомоги місцевими центрами з надання безоплатної вторинної правової допомоги, затверджені наказом координаційного центру з надання правової допомоги Міністерства юстиції України від 26 червня 2015 р. [9]

У процесі надання допомоги та захисту жертв насильства слід також зауважити про важливість недопущення повторної віктимізації постраждалих від торгівлі людьми, застосування не тільки загальних заходів безпеки таких осіб (особиста охорона, зміна документів, переселення в інше місце проживання та інше), але й додаткових (дистанційний допит потерпілого; впізнання поза візуальним і аудіо спостереженням особи, яку пред’явля- 
ють для впізнання; створення в судах спеціальних кімнат очікування для потерпілих; допит у режимі відеоконференції в процесі досудового розслідування та процесуальні дії у режимі відеоконференції під час судового провадження тощо).

Не можна забувати й про надання реабілітаційних соціально-психологічних послуг постраждалим від торгівлі людьми. При цьому важливо враховувати, що перелік потреб таких осіб залежить від гендерних особливостей. Наприклад, постраждалі від торгівлі людьми чоловіки соромляться звертатися за допомогою, вважаючи це ще більшим приниженням. Зважаючи на те, що причиною потрапляння чоловіка в ситуацію торгівлі людьми зазвичай є відсутність заробітку для забезпечення сім'ї необхідними умовами для повноцінного існування, заходи їх реабілітації обов'язково повинні включати послуги з перекваліфікації та працевлаштування. Допомогти якомога швидше повернути собі почуття самоповаги, здатності керувати своїм життям може забезпечити стабільна робота або відкриття власної справи. Що стосується розв'язування психологічних проблем, то важливою програмою може стати організація груп взаємодопомоги («зустріч із собі подібними»).

Погіршення загального стану здоров'я мають майже всі жінки, постраждалі від торгівлі людьми. У зв'язку із цим важливо забезпечити таку особу соціально-медичними послугами (посередництво в здійсненні профілактичних, лікувально-оздоровчих заходів; консультації з питань збереження і зміцнення здоров'я; подолання шкідливих звичок тощо). Конфіденційність надання допомоги жінкам, зокрема постраждалим від сексуальної експлуатації, є ключовою вимогою для запобігання повторній віктимізації постраждалих.

Украй складно визначити однотипну модель надання соціальної допомоги дітям, які потрапляють у ситуацію торгівлі людьми. Враховуючи особливі потреби дітей, важливо, щоб як медична, так і психологічна допомога була надана їм відразу після отриманої травми. Велике значення для ефективності реабілітаційних програм має оцінка ризиків та кроків самою дитиною, можливість влаштування в сім'ю (рідну чи прийомну) або іншу інституцію, яка буде сприйматися нею позитивно.

3. У 2003 р. між Міністерством України у справах сім’ї, дітей і молоді та Міжнародною організацією з мігрантів (MOM) підписана угода про співпрацю, у рамках якої передбачалося створення міжрегіональних центрів реабілітації жертв торгівлі людьми (Львові, Херсоні, Одесі, Чернівцях, Луцьку, Ж九итомирі).

Незважаючи на те, що в Україні діяльність міжнародних центрів реабілітації жертв торгівлі людьми відповідає міжнародним нормам і стандартам, на практиці реалізація вищезгаданої реабілітації поза межами цих закладів стикаєть- ся $з$ певними труднощами. В містах України, де відсутня система спеціальних закладів, допомога для постраждалих від торгівлі людьми надається в закладах соціального обслуговування, які опікуються переважно мешканцями регіону. Проте не в усіх регіонах держави наявні й такі установи, тому право на отримання послуг для постраждалих від торгівлі людьми у регіонах, де відсутні заклади соціального обслуговування, обмежене.

Інша проблема - умови та терміни перебування в таких центрах. Попри тенденцію до збільшення кількості чоловіків серед жертв торгівлі людьми, заклади соціального обслуговування переважно орієнтовані на роботу з дітьми і жінками. А щодо особливостей надання допомоги постраждалим від торгівлі людьми особам пенсійного віку, то в Україні на цей час такої практики немає.

Одним із важливих моментів під час надання соціальної допомоги постраждалим від торгівлі людьми є їх тимчасове розміщення у притулок (за бажанням постраждалої особи та в разі відсутності житла), на строк до трьох місяців, який за необхідності може бути продовжено за рішенням місцевої державної адміністрації. Зокрема, у зв'язку з участю особи як постраждалого або свідка у кримінальному процесі, ï може бути поселено в заклади цілодобового перебування. Водночас, як свідчить досвід інших країн, жертви торгівлі людьми мають право на більш тривалий період реабілітації без будь-яких умов (так, у Норвегії загальний термін - 6-місячний період, може бути продовжений на один рік у разі, якщо жертва співпрацює з органами влади з метою притягнення торговців до відповідальності).

4. У механізмі реалізації політики держави у протидії торгівлі людьми слід виділити такий позитивний складник: зважаючи на посилення внутрішньої міграції і появу значної кількості внутрішньо переміщених осіб (зумовлено окупацією окремих територій України), Міністерство соціальної політики разом з місцевими державними адміністраціями активізувало роботу з поширення інформації про ризики потрапляння громадян в ситуацію торгівлі людьми та можливості отримання допомоги постраждалим: розробляються макети соціальної реклами, друкуються плакати й буклети, розповсюджуються інформаційні матеріали в місцях скупчення людей, на веб-сайтах державних адміністрацій, у місцевій пресі тощо. При цьому, незважаючи на такі позитивні дії з боку органів державної влади у протидії торгівлі людьми, мають місце непоодинокі випадки непоінформованості правоохоронними органами жертв торгівлі людьми щодо їхнього права на відшкодування збитків та моральної шкоди. Проте це дуже важливо, оскільки відшкодування таких збитків поширюється лише щодо осіб, яких визнано потерпілими у судовому порядку, й цивільний 
позов можна подати тільки до початку судового розгляду справи по суті.

5. Під час реалізації політики держави у протидії торгівлі людьми слід враховувати той фактор, що будь-які позитивні сторони програми таких заходів завжди зводитимуться нанівець за відсутності належного фінансового забезпечення.

Незважаючи на те, що в українському законодавстві існують норми, які передбачають обов' язок відшкодування шкоди жертві, яка постраждала від торгівлі людьми, зокрема ст. 1177 Цивільного кодексу України [11], ст. 127 Кримінально-процесуального кодексу України [7], дуже важливо на законодавчому рівні визначити сам механізм компенсації, а також розглянути питання про створення і функціонування спеціального фонду відшкодування шкоди. Ані Державний бюджет України, ані місцеві бюджети не виступають основними донорами програм заходів протидії торгівлі людьми в нашій державі, основний тягар уже не один рік традиційно покладено на міжнародні й неурядові організації (у такому процесі ведеться активна співпраця з Координатором проектів ОБСЄ в Україні, Представництвом Міжнародної організації 3 міграції, Міжнародним жіночим правозахисним центром «Ла Страда - Україна»).

Таким чином, аналізуючи вищезазначене, можна констатувати, що загалом для реалізації державної політики у сфері протидії торгівлі людьми створена потужна юридична основа. Разом із тим формування такого нормативно-правового підІрунтя зовсім не гарантує остаточного зникнення самого негативного явища. Чимало вітчизняних нормативно-правових актів не є досконалими, саме тому окреслену в них проблему протидії торгівлі людьми слід розв' язувати системно у площині створення новітніх дієвих механізмів протидії такому злочину, консолідації зусиль усіх державних інституцій, спрямованих не тільки на запобігання так званому «білому рабству» і переслідування торговців, а й забезпечення безпеки, захисту та надання комплексної допомоги постраждалим.

\section{Jimepamypa}

1. Дивущак 0.0. Шляхи вдосконалення механізмів взаємодії органів державної влади та неурядових організацій у сфері протидії торгівлі людьми в Україні. $M o$ лодий вчений. 2016. № 4(31). С. 640-644.

2. Закон України «Про безоплатну правову допомогу» від 02.06. 2011 р. Відомості Верховної Ради Украйни. 2011. № 51. Ст. 577.

3. Закон України «Про протидію торгівлі людьми» від 16.05.2013 р. Відомості Верховної Ради Украӥни. 2012. № 19-20. Ст. 173.

4. Закон України «Про ратифікацію Конвенціі Ради Європи про заходи щодо протидії торгівлі людьми» від 21.09.2010 р. Відомості Верховної Ради України. 2011. № 5. Ст. 31.
5. Європейська конвенція про відшкодування збитків жертвам насильницьких злочинів ETS № 116 від 24. 11. 1983 p. URL: https://zakon.rada.gov.ua/laws/ show/994 319 .

6. Кримінальний кодекс України від 05.04.2001 p. Відолості Верховної Ради України. 2001. № 25-26. Ст. 131.

7. Кримінально-процесуальний кодекс від 13.04.2012 p. Відомості Верховної Ради Украӥни. 2013. № 9-10, № 11-12, № 13. Ст. 88.

8. Надання соціальних послуг різним групам осіб, які постраждали від торгівлі людьми : методичні рекомендації організації з безпеки та співробітництва в Європі (ОБСЕ). Київ : Фенікс, 2011. 62 с.

9. Наказ Міністерства юстиції України «Про затвердження Методичних рекомендацій щодо організації надання безоплатної вторинної правової допомоги місцевими центрами з надання безоплатної вторинної правової допомоги" від 26.06.2016 р. № 160. URL: http://consultant.parus.ua/?doc=090J628E04.

10. Філіпова Н. Державна політика протидії торгівлі людьми в Україні. Ефективність державного управління. 2011. Вип. 27. С. 179-185.

11. Цивільний кодекс України від 16.01.2003 p. Відомості Верховної Ради України. 2003. № 40-44. Ст. 356.

\section{Анотація}

Гураленко Н. А., Коханюк Т. С. Протидія торгівлі людьми в Україні: шляхи вдосконалення правової політики. - Стаття.

У статті здійснюється аналіз вітчизняної правової політики протидії торгівлі людьми та надаються рекомендації щодо шляхів її вдосконалення. Встановлено, що проблему протидії торгівлі людьми слід розв'язувати системно у площині створення новітніх дієвих механізмів протидії такому злочину. Наголошено на важливості взаємодії владних структур та неурядових громадських організацій у напрямі протидії торгівлею людьми. Акцентовано увагу на створенні розгалуженої мережі реінтеграційних, антикризових центрів реабілітації жертв торгівлі людьми. Зауважено щодо доцільності моніторингу процесів трудової міграції, програм регулярного навчання фахівців, які надають допомогу постраждалим у відповідній сфері. Зазначено про важливість активізації роботи правоохоронних органів у напрямі поінформованості не лише про ризики потрапляння в ситуацію торгівлі людьми, а й про особливості реалізації права на відшкодування збитків. Актуалізовано питання необхідності надання реабілітаційних соціально-психологічних послуг постраждалим від торгівлі людьми. Констатовано важливість недопущення повторної віктимізації постраждалих від торгівлі людьми, застосування не тільки загальних заходів безпеки таких осіб (особиста охорона, зміна документів, переселення в інше місце проживання та інші), але й додаткових (дистанційний допит потерпілого; впізнання поза візуальним і аудіоспостереженням особи, яку пред'являють для впізнання; створення в судах спеціальних кімнат очікування для потерпілих; допит у режимі відеоконференції в процесі досудового розслідування та процесуальні дії у режимі відеоконференції під час судового провадження та інше).

Ключові слова: протидія торгівлі людьми, правова політика, боротьба із злочинністю, надання допомоги постраждалим особам від торгівлі людьми, віктимізація постраждалих від торгівлі людьми. 


\section{Summary}

Huralenko N. A., Kohaniuk T.C.Combating trafficking in human beings in Ukraine: ways to improve legal policy. - Article.

The article analyzes the domestic legal policy of combating trafficking in human beings and provides recommendations on how to improve it. It is established that the problem of combating trafficking in human beings should be solved systematically in the field of creating the latest effective mechanisms for combating such crime. The focus is on the creation of an extensive network of reintegration, anti-crisis centers for the rehabilitation of victims of trafficking in human beings. It was noted that it is advisable to monitor the processes of labor migration, programs of regular training of specialists, who assist the victims in the relevant field. The importance of intensifying the work of law enforcement agencies in the direction of awareness not only about the risks of getting into the situation of trafficking in human beings, but also about the peculiarities of exercising the right to compensation for damages was noted. The need to provide rehabilitation social and psychological services to victims of trafficking in human beings has been updated.

The importance of preventing the re-victimization of victims of trafficking in human beings was stated, and not only the general security measures of such persons were applied (personal security, change of documents, relocation to another place of residence, etc.), but also additional (remote interrogation of the victim; recognition outside the visual and audio surveillance of the person being identified; creating special waiting rooms in the courts for the victims; interrogation in videoconference during pre-trial investigation and procedural actions in videoconference during court proceedings, etc.).

Key words: combating trafficking in human beings, legal policy, combating crime, assisting victims of trafficking in human beings, victimization of victims of trafficking in human beings. 